\title{
Maximilian Voloshin's classical metres
}

\author{
Igor Karlovsky \\ Tallinn \\ e-mail: igor@karlovsky.com
}

\begin{abstract}
Maximilian Voloshin turned to classical metres after he moved to Crimea that in his consciousness had associations with Hellas. Also, his friendship with Vyacheslav Ivanov became an important stimulus. Initially, Voloshin used the same metres that can be found in Ivanov's collection of poems Кормчие звезды. However, their form shows that Voloshin was well familiar with classical poetry.
\end{abstract}

\section{Introduction}

Maximilian Voloshin's return to Crimea after a prolonged stay in Paris to a considerable extent gave rise to the appearance of classical metres in his poetry starting from 1907. Following Greek authors, he called this land 'Cimmeria' (e.g. Hdt. IV. 11, 12, 45, etc.; Hom. Od. XI. 14; Strab. XI. 2. 4, 5, C 494, etc.), considering it a part of Hellas (Voloshin 2003-..., II: 79-80; V: 167-168; VI (1): 181-182; VI (2): 69-70, 82-83). The very landscapes here suggested iconic associations with classical metres: “Заливы гулкие земли глухой и древней, // Где в поздних сумерках грустнее и напевней // Звучат пустынные гекзаметры волны...." ["The sonorous bays of a desolate and ancient land, // Where in late twilight sorrowful and melodious // The deserted hexametricals of waves sound..."]; "Скалистых гор зубчатый окоем // Замкнул залив Алкеевым стихом, // Асимметрично-строгими строфами..." ["The toothed skyline of the rocky mountains // Closed the bay with the Alcaic verse, // With asymmetrically formal stanzas...”].

What was equally important was the influence of Vyacheslav Ivanov (see Kupchenko, Davydov 1990: 127). Although the young Voloshin moved to the Crimean Koktebel already in 1893, he updated the repertoire of verse forms only in close contact with the older poet. During this period he mastered not only rarely used complex models, but also ordinary metres like trochaic and iambic pentameters. Voloshin was on friendly terms with Ivanov, lodging in the same flat with him, attending poetic meetings in the 'Tower' and listening to 
his lectures on a theory of prosody. He also repeatedly named Ivanov among those few poets from whom he had learnt the craft of poetry, singling out Ivanov's collection of poems Кормчие звезды (1902) (Voloshin 2003-..., VII (2): 213, 214, 303, 306).

The various kinds of classical metres written by Voloshin during his initial attempts in 1907-1910 include only those present in Ivanov's collection. These are elegiac distich (“Аистихи"), Sapphics ("К Фантазии”, “Сафо”), Alcaics ("Пэстумский Храм”, “Молитва Камичл”, “Аовольно!”), galliambic ("Виноградник Аиониса"), and trochaic octameter (“Орфей”, "На Крыльях $3 a p u$ ”). Voloshin also experimented with classical metres, building on them to create his own forms similarly to Ivanov ("3емия", "Гипnа"). It is extremely significant that during this period Voloshin did not use the most popular classical metre - isolated dactylic hexameter - which is also absent from Кормчие звезды.

The statistical analysis in this article includes all the classical metres and their derivatives present in Voloshin's poetic heritage -31 texts, of which 30 are original poems and one is a translation. The bulk of the material comes from the Russian Academy of Science's Collected Works of Voloshin (Voloshin 2003-...). Several texts missing from that edition were found in the two-volume collection published in Paris by the YMCA Press (Voloshin 19821984).

\section{Classical metres}

\subsection{Dactylic hexameter}

Before his acquaintance with Ivanov, Voloshin only once tried his strength in classical metres in three hexametric poems in the series "Мысль $и$ форма" (1894) - “Аюдскому уму недоступны виденья из мира иного...", “Мысль и форма должны находится в гармонии полной..." and "Форма должна быть достойна в ней сказанной мысли...":

АюАскому уму недоступны виденья из мира иного, Все понимают кишь то, что могут увидеть глазами ИАь объяснить всем известным законом природы. А дух гениальный, в сознаньи невидимой силы, Сбросивши прочь человеческой мысли оковы, В безАне хаоса находит великие мысли и чувства, Которых понять невозможно толпе полудикой ... 
Like many Voloshin's early works, these are not perfect as regards form, nor do they meet the major requirements of the canon. Only feminine clausulae occur constantly, while lines in hexameter alternate with those in pentameter, which is barely distinguishable by ear, and zero anacruses with monosyllabic ones, which is typical of inexperienced authors. Such deviations, however, do not break the semantic halo of the metre and were actively developed as equivalent analogues of dactylic hexameter (Gasparov 1999: 221-226; Shapir 1994: 5361). Classical treatises on poetics from the school curriculum, for instance that of Horace (Voloshin later translated his poem "Весна" (1897)), would provide inspiration to create this didactic series.

Nevertheless, either such a genre was alien to the romantic mood of the novice poet, or else the metre seemed excessively academic to him. Therefore, his first attempt at the use of the classical metre did not evolve any further. Only in 1907 did Voloshin return to dactylic hexameter, this time including it in strophe compositions. One of them occurs in the poems "Полдень" and “Темны мики весны. Замутились влагой долины...":

Звонки стебли травы, и Авиженья зноя пахучи.

Горы, как рыжие мьвы, стали на страже пустынь.

В черно-синем огне расцветают медные тучи.

Горечью Аышит полынь ...

(“Поцдень")

$$
\begin{aligned}
& -\cup-\cup \cup-\mid \cup \cup-\cup-\cup \cup-\cup \\
& -\cup \cup-\cup \cup-\mid-\cup \cup-\cup \cup- \\
& -\cup-\cup \cup-\mid \cup \cup-\cup-\cup \cup-\cup \\
& -\cup \cup-\cup \cup-
\end{aligned}
$$

This stanza is Voloshin's own invention. As a base, he took a variant of Archilochians with an alternation of dactylic hexameter and trimeter (Voloshin 2003-..., I: 465), in which an early sketch of one poem is written. The doubling of odd trimeter lines, which made the first two lines metrically equal to elegiac distich, produced a new quatrain stanza. Perhaps, as a base, Voloshin took the elegiac distich (Scherr 1991: 523), which was supposedly invented by Archilochus as well. In this case, even pentameter lines are truncated by half.

The second combination making use of classical metre is found in the short poеm "Светло-зеленое море с синими полосами...", written in the same year: 
Светло-зеленое море с синими полосами,

Тонко усеяло небо мепестками розовых раковин.

Пиачут стекмянные волны ясными голосами,

Веет серебрянный ветер и играет звонкими травами ...

$$
\begin{aligned}
& -\cup|\cup-\cup \cup|-\cup|-\cup \cup| \cup \cup-\cup \\
& -\cup|\cup-\cup \cup|-\cup|\cup \cup-\cup|-\cup \cup \mid-\cup \\
& -\cup|\cup-\cup \cup|-\cup|-\cup \cup| \cup \cup-\cup \\
& -\cup|\cup-\cup \cup|-\cup|\cup \cup-\cup|-\cup \cup \mid-\cup \cup
\end{aligned}
$$

Alternation of pentameter and hexameter lines with zero anacruses, prevalent disyllabic intervals between ictuses and different clausulae resembles a deformed elegiac distich.

Elegiac distich proper appeared in Voloshin's poetry in 1910 as an anthological epigram when he inscribed gift copies of his debut collection of poems with the couplets " $B$ городе шумном построи ты храм Апомону Иикею...", “В горькой купели земли крещены мы огнем и тоскою...", “Вместе в один водоем поглядим ми мы осенью поздней..." and "Тысячелетнего сердиа семь раз воскресавшей Ардавды...":

В городе шумном построил ты храм Апомлону Аикею,

Я ж в Киммерии алтарь Горомедону возАвиг...

$-\cup \cup-\cup \cup-\cup \cup-\cup \cup-\cup \cup-\cup$

$-\cup \cup-\cup \cup--\cup \cup-\cup \cup-$

If Voloshin's early dactylic hexameter allows some deviations from the canon, the later ones are not just flawless, but unnaturally perfect. Although Russian poets usually render a quantitative verse by dol'nik with irregular intervals between ictuses to imitate the unequal number of syllables in the foot, Voloshin completed his elegiac distich by dactyl with a caesural truncation in even lines, and his derivatives by various logaoedics. In addition, the first stanza has a masculine caesura; in the second one, even the word boundaries in homogeneous lines take the same positions. Apparently, these peculiarities were caused by his experiments with Aeolics in this period. The mature Voloshin attached a great importance to the form of his works. Thus, his sonnets are considered by many as masterpieces of the genre (e.g. Ashukin 1929: 347; Grossman 1925: 126).

Most poems describe Crimean views ("Горы, как рыжие львы, стали на страже пустынь...", "Море глухо шумит, развивал древние свитки...", 
"Светло-зеленое море с синими полосами...") or directly mention toponyms of the land (“Я ж в Киммерии алтарь Горомедону воздвиг...", “Тысячелетнего сердиа семь раз воскресавшей Ардавды...”). No wonder a number of his inscriptions on watercolours from the 1920s contain local images embodied in dactylic hexameter and its five-foot derivative - "Волны земли омываются волнами моря...", “Голубые дали и гулы глубоких аулов...”, “Серень утра и серень прозрачных далей...", and “Тишина от муны, от хоммов и от скал Карадага..." (possibly more - “Бурые спины холмов // Над зеркальною зыюью залива...", “Камень, проникнутый воздухом далей, // Серьй и синий...”). As usual, Voloshin inscribed his paintings in syllabo-tonic verse, so that short, sometimes single-line, texts were perceived as poetic. Dactylic hexameter frequently expressed by dol'nik is the only exception. It has an easily recognized metric halo and requires no extra emphasis.

In general, Voloshin's constructing of classical metres proceeded differently after 1910. At this time, Voloshin actively developed irregular dol'nik of varying length with irregular alternation of unrhymed clausulae which was analogous to free verse, similarly both to his poetic consciousness (Trifonov 1991-1994, II: 384; Voloshin 2003-.., IV: 29-30) as well as the Russian literary tradition (Gasparov 1984: 180). For instance, poems from 1916 “Город”, “Аерево”, “Ауша города" and "Завоевание" were translated from Verhaeren using this metre. Its form resembles that of dactylic hexameter or elegiac distich, sometimes achieving full likeness with them. Thus, the influence of classical metres is especially evident in the final part of the polymetric translation "Завоевание":

Гавани, мипкие молы от Аегтя и вара,

Черные скмады, кипящие штольни, гудящие домны,

Ваша работа вяжет все уже узмы паутины

С тех пор, как золото, здесь на земле

Победимо золото неба!

Золото жизни, иль золото смерти, - страстное золото

Азию тянет петлей, промивается в Африку;

Золото скиптр океанов, бродячее золото,

С полюсов белых срывается к рыжим экваторам.

Золото блещет в побеАах, в разгромах мерцает,

Золото кружится в звездных орбитах веков,

Золото вцастно ведет в Аержавно намеченных планах

Мачты своих кораблей, рельсы своих поездов.

ВАОАь по пустыням земли, вАОль по воАам океанов ... 
Pentameter and hexameter lines are dominant (33 and 12 out of 50 total lines, respectively). Most of them have a zero anacrusis (46 lines) and a feminine clausula (31 lines). The interval between ictuses is overwhelmingly disyllabic (89.2\%) with only a sporadic monosyllabic interval (8.9\%) which, in keeping with the tradition, never appears before the last ictus, or zero interval $(2.0 \%)$ which, analogously to the classical pentameter, always appears after the third ictus. Deviations of disyllabic interval correspond to the Russian imitations of dactylic hexameter. The secondary rhythm curve of the first three intervals of pentameter and hexameter lines (11.1-2.2-22.2\%) is the most popular doublepeak curve with concentration of trochees on the first and the third feet (Gasparov 1975: 378-379; Shapir 1994: 51-52). The military subject introduced in world literature by Homer's Iliad could have stimulated the hexameter-like form of this poem.

In his subsequent translations made in irregular dol'nik (from de Régnier, in 1919), Voloshin returned to the domination of medium dimeter, trimeter and tetrameter lines, and a more natural distribution of anacruses and clausulae. However, the metrical features of “Завоевание” from Verhaeren were later used in Voloshin's original works. The classical metre appeared in the poem “Грядущзая Россия (nо Аристову)” (1922):

\footnotetext{
Ты вопреки всем невзгодам, разгромам и беАствиям

Миру Ааешь ежегодно три мимииона рук,

Множится пиемя твое на равнинных просторах,

Хватит земли на полтора мимлиарда мюдей.

Мощный русский язык, полнозвучный и гибкий,

Выковал и углубил многонапевный твой дух.

Пушкин, Толстой, Аостоевский - учители мира

Не Аля тебя ми нашли пронзительнейшие слова?

Ты сочетала в себе начала плоти и духа:

И созерцательность РуА, и Европейский потир.

Грезу свою преАпочиа осуществленному царству -

В вечных снегах подожгла неимоверный пожар...
}

The form became even more structured - lines shorter than pentameter disappeared entirely, while masculine clausulae alternated regularly with either feminine or dactylic clausulae. This text and Virgil's Aeneid are drawn together by the subject of statehood.

The development of this metre - the final stabilization of the line length at six feet, a constant zero anacrusis and regulated clausulae - appeared in the 
poem "Поэту революиии" (1923), which in 1925 was split into "Аоблесть поэта" and "Поэту":

Горн свой раздуй на горе, в пустынном месте наА морем

Человеческих множеств, чтоб голос стихии широко

Аушу крылил и качал, междометья мюдей заглушая.

Остерегайся Арузей, ученичества шума и славы.

Ученики развинтят и вывихнут мысли и строфы.

Только противник в борьбе может быть истинным Аругом.

Слава тебя прикует к глыбам твоих же творений.

Солнце мертвых - живым - она намогильный камень ...

(“Поэту”)

Here, the use of the metre is connected with the tradition of hexametric letters. It can be traced back to Ars Poetica, Horace's letters to Piso devoted to the subjects of poetry and a poet. Probably because the form does not meet all the features of the canon, Voloshin called it "liberated hexameter" (Voloshin 2003-..., II: 659).

Also in 1926, Voloshin inscribed the watercolour painting "Коктебельские бepeza" with a couplet written as an anthological epigram:

Эти пределы священны уж тем, что однажды под вечер

Пушкин на них погмядел с корабля по дороге в Гурзуф...

Despite its short length, the hexametric description of the Black Sea voyage undoubtedly refers to Homer's Odyssey.

However, the form of these poems differs both from the dactylic hexameter, due to the combination of a zero interval between ictuses at the caesura with a feminine clausulae, and from the elegiac distich, due to the absence of a zero interval with an alternation of masculine and feminine clausula. These deviations had already occurred earlier, in "Завоевание" from Verhaeren and in "Грядущал Россия (nо Аристову)".

The final stage of this poetic evolution was realized in the narrative poem "Четверть века (1900-1925)" (1927) written in an unrhymed dactylic tetrameter:

КажАый рожАается АважАы. Не я ли

В Аухе родился на стыке веков?

В год изначальный Авадцатого века 
Начал головокружительный бег.

Муарой судьбою закинутый в сердце

Азии, я ки не испытал

В АваАцать три гоАа всю горАость изгнанья

В рыжих песках туркестанских пустынь?

В жизни на этой магической грани

КажАый впервые себя сознает

Завоевателем древних империй

И заклинатемем будущих царств ...

Echoes of classical metre are noticeable in the basically dactylic rhythm, the infrequent deviations in the number of syllables between ictuses, and the absence of rhyme. The latter is characteristic of the dactylic hexameter, but was still uncommon in Voloshin's ternary metres, which, by the way, were abandoned by him after 1924. However, the shorter lines preserve an obvious semantic aura of antiquity (cf. Gasparov 1999: 224-225). Although Voloshin mainly employed narrative unrhymed iambic pentameter, subjects of wandering ("Мудрой судьбою закинутый в сердие // Азии...", “Я проходил по тропам Тамерлана...", “С чем мне сравнить микованье полета // Из Самарканда на запад - в Париж?..”) and war (“В этой звериной грызне государств...", "Но посреди ратоборства народов...", “В иквалах убийств, в исступленьи усобиц..."), common in Homeric epics, determined the form of this poem.

\subsection{Aeolics}

Voloshin's records in the second half of the 1900s illustrate his increased interest in the culture of classical antiquity. Thus, in 1907 he wrote in his notebook:

Аирик настраивает Аушу на известный размер. Русская мирика, настроенная мерой четырехстопного ямба. Ее заключитель Блок. Брюсов - заключитель хорея. Пора перестроить маА мирики на более сложные размеры, прикоснуться к размерам греческим. $-\cup-\cup-\cup \cup /-\cup-\cup:$ Аа будет это ритм моей мирики! Надо избрать один размер и усвоить его себе в совершенстве...

[A lyric poet tunes his soul to a certain metre. Russian lyric poetry has been tuned by the iambic tetrameter. Blok put an end to that metre. Bryusov put an end to the trochee. It is time to attune lyric poetry to more complicated metres, to reach out to Greek metres. $-\cup-\cup-\cup \cup /-\cup-\cup$ : let this be the rhythm of my lyrics! One must choose a single metre and master it to perfection...] (Voloshin 2000: 144) 
The Sapphic hendecasyllable presented in this scheme is one of the main classical metres and gave rise to other verse forms (Gasparov 1989: 57-58). Therefore, it was no wonder that in the same year Voloshin reconstructed Sapphics in the poem "Вещий крик осеннего ветра в поле...":

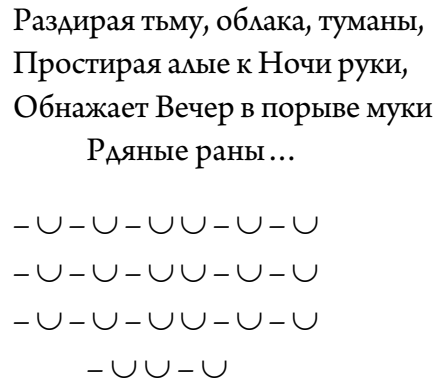

Curiously, Voloshin rhymed the very first classical metres ("Полденъ", "Светло-зеленое море с синими полосами...", “Вещий крик осеннего ветра в nоле..."), although archaic prosody did not yet know this device. Until this time he had almost never resorted to blank verse, with the exception of some texts in which rhyme is often excluded by the form itself, such as the Kalevala verse in "Расскажи, о, странник, Спарте..." (1891), the dactylic hexameter in the series of poems "Мысль и форма" (1894), an imitation of Lermontov's prose poetry in "Paccвem" (1894), and the free verse in "Tête Inconnue" (1904). Besides, the first Sapphics have no caesura that Russian poets, according from Roman examples, tried to keep in their works.

Voloshin wrote his first stanzas without rhyme and with caesura, such as Sapphic or Alcaic, in 1910. It should be noted that Voloshin's interest could have been stimulated when he became familiar with Alexander Peshkovsky's translations from Horace and subjected them to sharp criticism at the beginning of the year (Kupchenko 2002: 241, 248). Perhaps it was the unsatisfactory quality of these translations that pushed him to create his own.

Poетs “Аень молочно-сизыгй расивел и замер..." and "На пол пала мунная тень от рамы...” are written in Sapphics:

Обнимает сердце покорность. Тихо...

Мысли замирают. В саду маслина

Простирает ветви к слепому небу

Жестом рабыни...

(“Аень молочно-сизый расцвел и замер...”) 


$$
\begin{gathered}
-\cup-\cup-\cup \mid \cup-\cup-\cup \\
-\cup-\cup-\cup \mid \cup-\cup-\cup \\
-\cup-\cup-\cup \mid \cup-\cup-\cup \\
-\cup \cup-\cup
\end{gathered}
$$

Я одежаы сбросила, я нагая

Встала с можа узкого в светлом круге,

В тишине свершаются этой ночью

Аунные тайны...

(“На пом пала кунная тень от рамы...”)

$$
\begin{gathered}
-\cup-\cup-\cup \cup \mid-\cup-\cup \\
-\cup-\cup-\cup \cup \mid-\cup-\cup \\
-\cup-\cup-\cup \cup \mid-\cup-\cup \\
-\cup \cup-\cup
\end{gathered}
$$

Despite the presence of a complete pause in both texts, in the first one the caesura is feminine after the sixth syllable, while in the second one it is dactylic after the seventh. Moreover, the traditional caesura, one that was introduced by Horace and taken over by the Russian canon, was masculine after the fifth syllable. Evidently, Voloshin's Sapphics are formed by crossing two poetic traditions - the Roman tradition in which the caesura was used, and the Greek one in which it was not. Voloshin left a complete pause in his poems, but he effectively hid it by placing it in unusual locations.

All three texts include classical motives and images ("Вопли Аеметры...", "В саду маслина // Простирает ветви $к$ слепому небу // Жестом рабыни...”). These are, however, especially pronounced in the form and the semantic connection of "На пол пала луннал тень от рамы..." The bold content of this poem narrated on behalf of a woman in combination with the Sapphics suggest associations with the poetess from Lesbos. Moreover, the subjects of love and religion, typical of her lyrics, become apparent as reminiscences from the biblical Song of Songs (Voloshin 2003-..., II: 722).

Alcaics are developed in the poems "С тех пор как тяжкий жернов слепой судьбы..." and "Седым и низким облаком дол повит... ": 
КогАа глубокой ночью я в первый раз

Поверил правде пристальных глаз твоих

И прочитал изгиб твоих губ -

Аревние тайны в Ауше раскрылись...

(“С тех пор как тяжкий жернов слепой судьбы ...”)

В морщине горной, в складках тисненых кож

Тускнеет сизый блеск чешуи морской.

Скрипят Аеревья. Вихрь траву рвет,

Треплет кусты и разносит брызги...

(“Седым и низким обкаком дол повит...”)

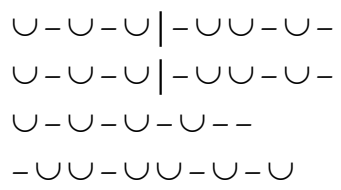

The last longum of the 11-syllabic lines of classical Alcaics is the third syllable from the end $(\ldots-\cup \mathrm{X})$, but in the 9- and 10-syllabic lines it is the second from the end $(\ldots-\mathrm{X})$. An anceps, which could be represented in a syllabo-tonic verse either by a stressed or unstressed syllable, concluded all the lines. Russian poets varied masculine or dactylic clausulae of the first two lines, while a clausula of the last lines always remained feminine, as the masculine one assumes a monosyllabic word. To enhance the resemblance to classical Alcaics, in his own imitations Voloshin always put stress not only on the final syllables of the 11syllabic lines, but on those of the 9-syllabic lines as well.

The love lyric "С тех пор как тлжкий жернов слепой судьбы...", dedicated to the poet Elisaveta Dmitrieva, in conjunction with its form is a reference to the epistle of Alcaeus" "To Sappho" and the landscape lyric "Седым и низким облаком дол повит..." from the series of poems "Киммерийскал весна" - to Alcaeus' "Spring". Moreover, Voloshin's Alcaics have thematically much in common with the above-mentioned Sapphics - "На пол пала лунная тень от рамы..." and "Аень молочно-сизый расивел и замер...", respectively. The last poem was initially included in the series "Киммерийскал весна" (Voloshin 1911: 46).

Experiments with Aeolics affected Voloshin's own metres and were realized in the logaoedic of the same year "Облака клублтся в безднах зеленых..." 
И звенит и блещет белый стекмярус

За Киик-Атламой костистой,

Пиещет в синем ветре Аымчатый парус,

Мнеет слеА струистый...

$$
\begin{gathered}
-\cup-\cup-\cup \mid-\cup \cup-\cup \\
-\cup-\cup \cup-\cup-\cup \\
-\cup-\cup-\cup \mid-\cup \cup-\cup \\
-\cup-\cup-\cup
\end{gathered}
$$

In this poem, the combination of three different line types correlates with Alcaics, and the short last line after three long lines with Sapphics. Moreover, the odd 11-syllabic lines with a single disyllabic interval between ictuses among monosyllabic intervals are reminiscent of Alcaic and Sapphic hendecasyllables (Scherr 1991: 524). Whereas later classical metres were already written in blank verse, in the derivative Voloshin returned to his more usual rhyme. In "Облака клублтся в безднах зеленых..." he adopted not only the form, but also the subject of the initial examples - a spring scenery of Koktebel. Together with "Седым и низким облаком дол повит..." and "Аень молочно-сизый расивел и замер..." they constituted the series of poems "Киммерийскал весна".

In his later Aeolics Voloshin developed free verse, similarly to his hexametricals of the same period. The form of the poem "Иyda-anocmos", which he started writing in 1910 and finished only in 1919, represents irregular dol'nik with irregular alternation of unrhymed clausulae. Its first four lines consist of Sapphics with Voloshin's customary dactylic caesura:

И когАа приблизился празАник Пасхи,

В первый Аень опресноков в час вечерний

Он возмег за трапезу - с ним Авенадцать В горнице чистой...

The subsequent lines reveal considerable deviations from the canonical form:

\footnotetext{
“В этом мире цари первенствуют:

Вы же не так - кто больший, будет как меньший.

Завещаю вам Свое царство.

Сядете судить на Авенадцать тронов,

Но одним из вас Я буАу преАан.

Так преАназначено, но преАателю горе!”
} 


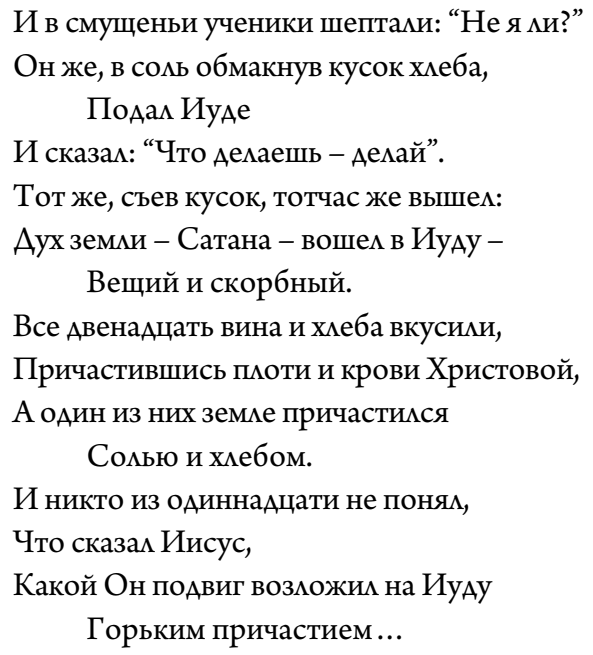

However, characteristically of Aeolian logaoedics, the alternation mainly of pentameter and dimeter lines ( 26 and 11 out of 53 total lines, respectively) is retained. A zero anacrusis (49 lines) and a feminine clausula (46 lines) predominate, as does a monosyllabic interval $(62,4 \%)$ - although a disyllabic interval is more common in Russian metres with a varying number of syllables between ictuses (Gasparov 1974: 234-235; Gasparov 1993: 137-138). The dimeter lines, most of which are dactylic with a feminine clausula and thus correspond to classical adonic ( 8 lines of 11 ), are usually connected to the previous line by enjambment, as the tradition dictates ("Он возлег за трапезу с ним двенадиать // В горнице чистой...", “А один из них земле причастися // Солью и хлебом...", "Какой Он подвиг возложил на Иуду // Горьким причастием...", “Аегли ему на уста. И в них узнал он // Руку Иуды...”). Тhе last Sapphic hendecasyllable and adonic are considered as one line in classical poetry, since a syntactic pause or, sometimes, word boundary between them is absent.

Attention should be drawn to the graphic composition of "Иyda-anocmos" with its indentation of shorter lines. Voloshin used it only in regular metres of varying length, including Sapphics, whereas in irregular metres, including irregular dol'nik and free verse, he aligned all the lines. The form of the poem could be determined by its religious subject characteristic of Sappho's hymns.

The presence of classical metres in Voloshin's irregular dol'nik (in "Завоевание" from Verhaeren and "Иуда-апостол") could be explained by the genetic relationship between the two. It is well known that German pre- 
romanticists tried to reproduce complicated rhythms of Pindar's choral lyrics that were perceived as prose divided into lines - in free verse (Gasparov 1984: 180; Gasparov 1989: 254).

\title{
2.3. Adonic
}

In classical literature, an adonic was a part of Sapphics, or just a part of its last line. Later, it was separated into an independent metre, having kept the genre features of classical hymns to which it owes its name. Voloshin made an attempt to reproduce an isolated adonic in the poem "Гностический гимн Аеве Mapuu" (1906):

\author{
Майею в мире \\ РожАается Будаа. \\ В областях звезаных \\ НаА миром царит. \\ Верьте свершителю \\ Вышнего чуда: \\ Пиамя, угасшее в безднах, - \\ Горит!..
}

\section{Майа - Мария!..}

Its form, however, indicates classical heritage. "Гностический гимн Аеве Марии" is dedicated to Vyacheslav Ivanov, whose poem "Ието Господне" (before 1904) obviously served as an example. Voloshin replaced irregular rhymes, sometimes located far apart in Ivanov's poem, with the correct alternation of unrhymed and rhymed clausulae. After odd lines he used a compensating anacrusis instead of a zero one. Thus, the metre of the poem is done in dactylic tetrameter split into two parts. Lines other than two feet ("Пламл, угасшее в безднах, - // Горит!..") and the early version of "Гностический гимн Аеве Марии" (Voloshin 1908; Voloshin 1909: 379-380; Voloshin 2003-.., VI (2): 233) also display affectation and insignificance of the graphic composition. Metric inertia of dactylic tetrameter disrupts the refrain always expressed by one dactylic dimeter with a feminine clausula (“Mope - Mapus!..”, “Майa - Mapus!..”, “Ave Maria!..”). Similar alternation of several long lines with an adonic is a direct reference to Sapphics (Gasparov 1993: 121-122). A zero anacrusis, prevailing feminine clausula and the length 
of dactylic tetrameter, correlated by the number of syllables with Sapphic hendecasyllable, intensify this association.

The short length of adonic makes it possible to convert it without losing its semantic halo to the adjacent metres - iamb, amphibrach, dol'nik and others (Gasparov 1999: 285; Lotman 1988: 129-130). Voloshin's poem "He mol งu..." (1915) illustrates such a transformation:

\author{
Не ты ми \\ Неволик разум \\ Принять свершенье \\ Непостижимых \\ Твоих путей \\ Во всем гореньи \\ Противоречий, \\ Несовместимых \\ Амя человечьей \\ Стесненной мысми?..
}

Its larger part is written in an iambic dimeter ( 38 out of 52 lines total), but dactylic ("Густо и крепко..."), amphibrachic (“Слезами и кровью...") and anapaestic ("Oтнял силу у рук...") lines also occur. The poem bears metrical features of Goethe's hymns "Gesang der Geister über den Wassern" (1779), "Meine Göttin" (1780), "Das Göttliche" (1781), and "Grenzen der Menschheit" (1781). Voloshin rediscovered Goethe's poetry in the mid-1910s thanks to Rudolf Steiner.

"Гностический гимн Аеве Марии" and "Не ты ми..." fit the genre quite well, as both are direct appeals to God. The first poem includes characters and symbols of Vedic, Buddhist, Greco-Roman and Biblical mythologies (Voloshin 2003-.., I: 462-463), the second those from the Book of Revelation (Voloshin 2003-..., I: 516).

\title{
2.4. Galliambic
}

In 1907, simultaneously with hexametricals and Sapphics, Voloshin also reproduced a galliambic in the poem "Я иду дорогой скорбной в мой безрадостный Коктебель...”: 
Я иАу Аорогой скорбной в мой безрадостный Коктебель ...

По нагорьям терн узорный и кустарники в серебре.

По Аолинам тонким дымом розовеет внизу миндаль,

И кежит земля страстная в черных ризах и орарях...

$-\cup-\cup-\cup-\cup-\cup-\cup \cup-\cup-$

The form of the poem conveys distinctive features of classical galliambic, generally known by Catullus' "Attis", the only completely preserved work in this metre. They are manifest in the cluster of four short brevum before the last longum, as in five of eight Voloshin's lines (“безрадостный Коктебель...", “кустарники в серебре...", “ризах и орарях...”, “задыхающейся волны...”, “торжественный Коктебель!..”) (Gasparov 1994: 201), end and internal assonances (“скорбной-узорный”, “Коктебель-серебре”, “миндаль-орарях”, “гор-чело”, “мятой-распятый”) and consonances ("Коктебель-миндаль”), making a metrical and semantical loop (Dobritsyn 1993: 306-307).

In creating his poem, Voloshin considered not only the form of galliambic, but also the meaning of Catullus' work that narrates about Attis' sufferings and its system of figures. Passionate subjects and chthonic symbolics run through the entire poem (Dobritsyn 1993: 300-303). Even reasons behind the writing of "Я иду дорогой скорбной в мой безрадостный Коктебель..." and "Attis" are similar - both texts are inspired by troubles in the private lives of their authors (Dobritsyn 1993: 305).

\subsection{Trochaic octameter}

Another classical metre, the trochaic octameter is used by Voloshin in the

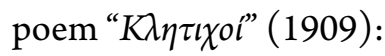

Ты - целитель! Ты - Ааятель! Отвратитель тусклых беА!

Гневный мститель! Насылатель черных язв и знойных мет!

Аегких Ор святые хоры ты уводишь, КифареА!..

$-\cup-\cup-\cup-\cup \mid-\cup-\cup-\cup-$

In the early 20th century, trochaic octameter was the most commonly used extralong metre (Bailey 1971: 124; Gasparov 1984: 211). This may have been so because of its specific feature - an obligatory caesura and frequently rhymed 
pair of masculine clausulae, so that couplets of trochaic octameter may be perceived as quatrains of trochaic tetrameter with the alteration of feminine and masculine clausulae. An additional internal rhyme on a caesura creates the most popular type of Russian stanza - AbAb. A similar partition of iambic octameter's lines into hemistich is evident in the alternation of clausulae in a less usual order $-\mathrm{aBaB}$.

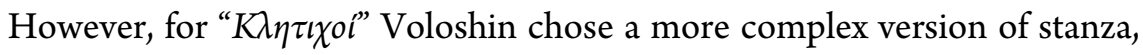
for which poems by Konstantin Balmont might have provided an example. In particular, Balmont applied a combination of trochaic octameter with a triple masculine rhyme in the poem "Ворожба" (1903). Later he repeated this with added irregular internal rhymes on two occasions - in the poems "Тень-Река" and "Аyx Брачующий" (before 1909). Voloshin also made use of the technique in " $K \lambda \eta \tau \imath \chi \circ$ ".

The tercet stanza is interrelated with the three-part movement of the classical Greek chorus and a tradition of roundelay in general (Gasparov 1989: 63). While Balmont expressed a clear association with folklore and his metre may be perceived as a double trochaic tetrameter, for Voloshin the classical halo is more important, and his metre is an equivalent of trochaic octameter, which is evident in its form and semantics. In "K $\lambda \eta \tau \imath \chi o$ ", the average percentage of stresses is $87.5 \%$, whereas in the Russian trochaic tetrameter it rose to nearly 77\% (Gasparov 1974: 98; Taranovsky 1971: 424). Such a large figure refers to quantitative verse in which each foot has an obligatory longum, unlike syllabo-tonic verse that allows omission of stresses. Absolute stressing of even ictuses (77.8-100.0-85.2-100.0-77.8-100.0-59.3-100.0\%) and coincidence of the majority of even foot boundaries with word boundaries (11.1-66.7-29.6-70.4-22.2-63.0-0.0-100.0-11.1-66.7-37.0-51.9-40.7$29.6 \%$ ) have the purpose of conveying the dipodic structure of the classical metre.

In classical Greek drama, trochaic octameter was used according to its literal meaning ('running', 'dancing') to highlight more dynamic scenes against a neutral background of iambic hexameter (Gasparov 1989: 76). These associations were important for Voloshin. As in the poem, he did not simply address classical subjects, but also described the run of Apollo's chariot (“Зарный бог несется к югу в сталх бельх лебедей...") and the dance of the Muses accompanying him (“Быстрый танеи, вдоль по мугу бельй вихрь одежд развей!..”). 


\section{Conclusion}

Voloshin perceived the classical metres through the prism of Vyacheslav Ivanov, except for the isolated dactylic hexameter in the series of early poems "Мысль и форма", and late derivatives developed from free verse. The flourishing of Voloshin's classical metres coincided with the period of his close contacts with Ivanov and their range is identical to that of Ivanov. Afterwards, when the relationship between the poets became more distant, Voloshin ceased to follow strict principles of the canon and abandoned the use of classical metres. However, Ivanov's works were a significant catalyst rather than a direct source of borrowing. The specific features of Voloshin's metres show that the author was well familiar with classical poetry.

\section{References}

Ashukin 1929 = Ашукин, Николай Сергеевич (ed.) 1929. Валерий Брюсов в автобиографических записях, письмах, воспоминаниях современников и отзывах критики. Москва: Фелерация.

Bailey, James 1971. Russian binary meters with strong caesura from 1890 to 1920. International Journal of Slavic Linguistics and Poetics 14: 111-133.

Dobritsyn 1993 = Аобрицын, Андрей Александрович 1993. Галииямб у Волошина (в поисках семантики метра). Russian Linguistics: International Journal for the Study of the Russian Language 17(3): 299-312.

Gasparov 1974 = Гаспаров, Михаил Аеонович 1974. Современный русский стих: Метрика и ритмика. Москва: Наука.

- 1975. Продром, Цец и национальные формы гексаметра. In: Фрейберг, Аидия Анатольевна (ed.), Античность и Византия. Москва: Наука, 362-385.

- 1984. Очерк истории русского стиха: Метрика. Ритмика. Рифма. Строфика. Москва: Наука.

- 1989. Очерк истории европейского стиха. Москва: Наука.

- 1993. Русские стихи 1890-х-1925-го годов в комментариях. Москва: Высшая школа.

- 1994. Фригийский стих на вологодской почве. Russian Linguistics: International Journal for the Study of the Russian Language 18(2): 197-204.

- 1999. Метр и смысл: Об одном из механизмов культурной памяти. Москва: Российский государственный гуманитарный университет.

Grossman 1925 = Гроссман, АеониА Петрович 1925. Поэтика сонета. In: Брюсов, Валерий Яковлевич (ed.), Проблемы поэтики: Сборник статей. Москва, АенинграА: Земля и фабрика, 115-140.

Kupchenko 2002 = Купченко, Владимир Петрович 2002. Труды и дни Максимилиана Волочина: Аетопись жизни и творчества. 1877-1916. Санкт-Петербург: Алетейя. 
Kupchenko, Davydov 1990 = Купченко, Владимир Петрович; Аавыдов, Захар Аавыдович (eds.) 1990. Воспоминания о Максимилиане Волошине. Москва: Советский писатель.

Lotman 1988 = Аотман, Михаил Юрьевич 1988. Русский стих. Семантика стихотворного метра в русской поэзии второй половины XIX века (А. А. Фет и Н. А. Некрасов). In: Pszczołowska, Lucylla (ed.), Stowiańska metryka porównawcza. III: Semantyka form wierszowych. Wrocław, Warszawa, etc.: Zakład Narodowy imienia Ossolińskich Wydawnictwo Polskiej Akademii Nauk, 105-143.

Shapir 1994 = Шапир, Максим Ильич 1994. Гексаметр и пентаметр в поэзии Катенина (О формально-семантической деривации стихотворных размеров). Philologica: Авуязычный журнал по русской и теоретической филологии [Bilingual Journal for the Study of Russian and Theoretical Philology] 1(1/2): 43-107.

Scherr, Barry P. 1991. Maksimilian Voloshin and the search for form(s). Slavic and East European Journal 35(4): 518-536.

Taranovsky 1971 = Тарановский, Кирим Федорович 1971. О ритмической структуре русских Авусложных размеров. In: Алексеев, Михаил Павлович et al. (eds.), Поэтика и стилистика русской митературы: Памлти академика Виктора Владимировича Виноградова. АениниграА: Наука, 420-429.

Trifonov 1991-1994 = Трифонов, Николай Алексеевич et al. (eds.) 1991-1994. Валерий Брюсов и его корреспонденты. Москва: Наука.

Voloshin 1908 = Волошин, Максимилиан Александрович 1908. Гностический гимн. Вестник теософии: Религиозно-философско-научный журнал 2 (7 февраля): 58-59.

- 1909. Автобиография. Стихотворения. In: Гофман, Модест АюАвигович (ed.), Книга о русских поэтах последнего десятилетия: Очерки. Стихотворения. Автографы. Санкт-Петербург, Москва: Товарищество М. О. Вольф, 365-380.

- 1911. Киммерийская весна. In: Антология. Москва: Мусагет, 41-50.

- 1982-1984. Стихотворения и поэмы: В 2 томах. Paris: YMCA-Press.

- 2000. Записные книжки. Москва: Вагриус.

- 2003-... Собрание сочинений. Москва: Эмлис Аак 2000.

\section{Античные размеры Максимилиана Волошина}

К античным размерам Максимилиан Волошин обратился после переезАа в Крым, который ассоциировался в его сознании с Эммадой. Важным стимумом стала также Аружба с Вячеславом Ивановым. Первоначально Волошин ограничивался теми же размерами, которые встречаются в сборнике Иванова «Кормчие звезды». Тем не менее, их формальные особенности свидетельствуют о хорошем знакомстве Волошина с классической поэзией. 


\section{Maksimilian Vološini antiiksed värsimõõdud}

Maksimilian Vološin pöördus antiiksete värsimõõtude juurde pärast kolimist Krimmi, mis assotsieerus tema teadvuses Hellasega. Oluliseks stiimuliks kujunes ka sõprus Vjatšeslav Ivanoviga. Algul kasutas Vološin samu värsimõõte, mida võib leida Ivanovi luulekogus “Кормчие звездьъ". Siiski näitab nende vorm, et Vološin oli klassikalise luulega hästi tuttav. 